\title{
Soil Testing as a Tool for On-Farm Fertility Management: Experience from the Semi-arid Zone of India
}

\author{
KANWAR L. SAHRAWAT AND SUHAS P. WANI \\ International Crops Research Institute for the Semi-arid Tropics (ICRISAT), \\ Andhra Pradesh, India
}

\begin{abstract}
Rainfed agriculture in the dry regions is affected by water shortages. Our earlier research showed that the deficiencies not only of major nutrients but also those of sulfur $(S)$ and micronutrients are holding back the potential of agricultural production systems. The objectives of this article are to discuss the efficacy of soil testing to diagnose nutrient deficiencies using 28,270 diverse soil samples collected from farmers' fields in the semi-arid tropical (SAT) regions of India and to confirm the efficacy of the soil test-based balanced nutrient management in enhancing productivity of a range of crops in on-farm farmer participatory trials under rainfed conditions. Results of a large numbers of on-farm trials demonstrated that soil testing is indeed an effective tool for on-farm fertility management, a prerequisite for sustainably enhancing the productivity in rainfed areas in the SAT regions of India. The need to strengthen the soil-testing infrastructure in the country is emphasized.
\end{abstract}

Keywords Balanced nutrient management, crop productivity and quality, diagnosis of nutrient problems, soil quality, soil test-based recommendation, water shortage, water-use efficiency

\section{Introduction}

In the rainfed production systems, the importance of water shortage and associated stress cannot be overemphasized, especially in the semi-arid tropical (SAT) regions (Pathak et al. 2009; Passioura and Angus 2010; Rockström et al. 2010; Sahrawat et al. 2010a; Sharma et al. 2010). However, apart from water shortage, soil infertility is also an issue for crop production and productivity enhancement in much of the SAT regions of the world, and Indian SAT is no exception (El-Swaify et al. 1985; Black 1993; Zougmore et al. 2003; Sahrawat et al. 2007, 2010b; Singh 2008; Bationo et al. 2008; Twomlow, Love, and Walker 2008; Bekunda et al. 2010).

Apart from the deficiencies of major nutrients, nitrogen $(\mathrm{N})$ and phosphorus $(\mathrm{P})$, the deficiencies of secondary nutrients, especially of sulfur $(\mathrm{S})$ and micronutrients, have been reported with increasing frequencies from the intensified irrigated production systems (Kanwar 1972; Pasricha and Fox 1993; Takkar 1996; Scherer 2001, 2009; Fageria, Baligar, and Clark 2002; Singh 2008). Although in the irrigated systems the deficiencies of various

Received 2 July 2011; accepted 14 December 2011.

Address correspondence to Kanwar L. Sahrawat, International Crops Research Institute for the Semi-arid Tropics (ICRISAT), Patancheru 502 324, Andhra Pradesh, India. E-mail: k.sahrawat@ cgiar.org 
plant nutrients have been diagnosed through soil and plant testing and managed through the fertilization of crops, little attention seems to have been paid to diagnosing the deficiencies of secondary nutrients such as $\mathrm{S}$ and micronutrients in dryland rainfed production systems, especially in SAT India (Sahrawat et al. 2007; Sahrawat et al. 2010b).

Specifically, little attention has been devoted to surveying and determining the fertility status of farmers' fields to diagnose the nutrient problems in the rainfed production systems, which is a prerequisite for developing an effective nutrient-management strategy for enhancing agricultural productivity in these areas. Lack of adequate analytical laboratory support infrastructure in developing countries coupled with the lack of awareness that the mining of secondary and micronutrients in production systems is not helping the cause of upgrading the rainfed agriculture. The information on the soil fertility status is needed not only to enhance crop productivity through balanced nutrient management but also to promote judicious use of costly external inputs of nutrients and enhance the efficiency of scarce water resources in developing countries such as India (Sahrawat 2006; Wani 2008).

This apparent paradox of lack of application of adequate amount of nutrients from external inputs (Bationo et al. 2008; Katyal 2003) despite the common knowledge that the soil resource base in the rainfed systems of the SAT regions is relatively fragile and marginal compared to that under the irrigated production systems (El-Swaify et al. 1985; Rego et al. 2003; Sahrawat et al. 2007, 2010b) is inexplicable.

In the rainfed systems of India, the management of water shortage has been the primary focus of research and developmental activities in these areas, and soil infertility has largely been ignored (El-Swaify et al. 1985; Wani et al. 2003; Sahrawat et al. 2010a, 2010b) or has not been addressed in an integrated manner along with soil and water conservation practices (Wani et al. 2009; Rockstrôm et al. 2010).

However, even in water-limiting environments, there is potential to enhance agricultural productivity through efficient management of soil, water, and nutrients in an integrated manner (Wani et al. 2002; Twomlow, Love, and Walker 2008; Wani et al. 2009; Sahrawat 2010b). To achieve the potential of productivity in water-limited environments, a concept of water-limited potential yield seems very appropriate as this forms the basis to reach the attainable yield in these environments through management of various constraints other than just water shortage (Passioura 2006; Singh et al. 2009). For example, in Australia, farmers have adopted the notion of water-limited potential yield as a benchmark for yield and if farmers find that their crops are performing below the benchmark, they look for the reasons and attempt to improve their management accordingly (Passioura and Angus 2010). We emphasize that in the concept of water-limited potential yield in the rainfed systems, natural resource management in general and soil fertility management in particular need to be paid due attention along with water-stress management in view of the fragile nature of the soil resource base (Sahrawat 2010a, 2010b; Wani et al. 2009).

Moreover, it is a commonly held belief that at relatively low yields of crops in the rainfed systems of India, the deficiencies of major nutrients, especially those of $\mathrm{N}$ and $\mathrm{P}$, only are important for the SAT Indian soils (El-Swaify et al. 1985; Rego et al. 2003) and consequently little attention has been devoted to diagnose the extent of deficiencies of the secondary nutrients such as $\mathrm{S}$ and micronutrients in various crop production systems on millions of small and marginal farmers' fields (Rego et al. 2005, 2007; Sahrawat et al. 2007, 2010b).

It is recognized and duly emphasized that the productivity of the SAT soils is low due to water shortages. Although poor fertility is an issue, in practice the deficiencies of major nutrients $(\mathrm{N}$ and $\mathrm{P})$ are considered important and the role of secondary and micronutrients in enhancing water-use efficiency is neglected. Moreover, the input of major nutrients to 
dryland production systems is meager compared to that in the irrigated systems (Rego et al. 2005; Wani et al. 2009). Also, because of the low productivity of the rainfed crops, it is generally assumed that the offtake and mining of micronutrient reserves in soils is much less than in irrigated production systems (Rego et al. 2003).

For sustained increase in dryland productivity, soil and water conservation measures need to be integrated with plant nutrition and choice of crops and their management (Wani et al. 2003; Passioura 2006; Passioura and Angus 2010; Sahrawat et al. 2010a). The ongoing farmer participatory integrated watershed management program of the ICRISAT (International Crops Research Institute for the Semi-arid Tropics) provided an appropriate opportunity to implement nutrient-management strategy alongside soil and water conservation practices in farmers' fields in the Indian semi-arid tropics. For achieving efficient and judicious use of nutrients through fertilizer inputs, assessing the soil's inherent nutrient status is a prerequisite (Sahrawat 2006).

The objectives of this article therefore are to review, analyze, and present recent results on the general fertility status of soils in the rainfed systems with emphasis on the deficiencies of secondary and micronutrients and to confirm the efficacy of the soil-test-based nutrient-management strategy to increase the productivity of a range of crops in farmer participatory on-farm trials in the rainfed systems of the SAT regions. Preference is given to the results generated from the on-farm research in the SAT regions of India. First, the results on the fertility status of SAT soils are addressed, followed by the response of various food crops to balanced nutrient management considering the various nutrient deficiencies under the on-farm conditions. Equally importantly, the role of soil testing in the diagnosis of nutrient deficiencies has been demonstrated and hence emphasized.

\section{Materials and Methods}

\section{Diagnosis of Nutrient Deficiencies by Soil Testing}

Since 1997, the natural resources management group at the ICRISAT center in India along with its partners has been conducting systematic and detailed studies on the diagnosis and management of nutrient deficiencies in the semi-arid regions of Asia with emphasis on India. It started with detailed analysis of farmers' fields in Milli watershed at Lalatora in Madhya Pradesh, where analysis of soil samples for micronutrients was deliberately included as a part of the baseline characterization of the site.

First a soil sampling methodology was developed and standardized to collect representative soil samples in a watershed. The methodology is based on the stratified random sampling of the watershed considering the soil types including topography, major crops, and farmers' land holding size (for details see Sahrawat et al. 2008b). For effective soil sampling, farmers' fields were divided into three groups based on the position on the toposequence: top, middle, and bottom, depending on the elevation and drainage pattern. We separated different soil types in each category. For soil sampling, we randomly selected $20 \%$ farmers in each position on the toposequence, in proportion to the farm size, types of soils, and crops grown (see Sahrawat et al. 2008b). The soil sampling program of watersheds in various states was undertaken largely during 2002-2009.

Using stratified random sampling methodology (Sahrawat et al. 2008b), we collected 8 to 10 cores of surface ( 0 - to $15-\mathrm{cm}$ depth) soils to make one composite sample. The soil samples were air dried and powdered with wooden hammer to pass through a 2-mm sieve. For organic carbon (C) analysis, the soil samples were ground to pass through a $0.25-\mathrm{mm}$ 
sieve. Prepared samples were analyzed for various fertility characteristics in the ICRISAT Central Analytical Services Laboratory.

To characterize the fertility status of soils under dryland agriculture in the SAT regions of India, we collected 28,270 soil samples from farmers' fields in the Indian states of Andhra Pradesh, Karnataka, Rajasthan, and Madhya Pradesh. The number of farmers cultivating arable land varied along with land holding size, crops, and cropping systems.

For soil analysis, $\mathrm{pH}$ was measured by a glass electrode using a soil-to-water ratio of 1:2. Organic carbon (C) was determined using the Walkley-Black method (Nelson and Sommers 1996). Exchangeable (available) potassium (K) was determined using the ammonium acetate method (Helmke and Sparks 1996). Available S was measured using $0.15 \%$ calcium chloride $\left(\mathrm{CaCl}_{2}\right)$ as an extractant (Tabatabai 1996; Sahrawat et al. 2009); available $\mathrm{P}(\mathrm{Olsen} \mathrm{P})$ was measured using sodium bicarbonate $\left(\mathrm{NaHCO}_{3}\right)$ as an extractant $(\mathrm{Olsen}$ and Sommers 1982). Available zinc (Zn) was extracted by diethylenetriaminepentaacetic acid (DTPA) reagent (Lindsay and Norvell 1978) and available boron (B) was extracted by hot water (Keren 1996).

Based on the results of soil samples collected from farmers' fields, recommendations were developed at the block level for balanced nutrient management. For this, critical limits in the soil for various plant nutrients were used (Table 1) to separate deficient soil samples from the nondeficient ones (Sahrawat 2006; Rego et al. 2007; Sahrawat et al. 2007) for the follow-up on-farm crop response studies.

\section{On-Farm Crop Responses to Soil-Test-Based Fertilization}

During 2002-2009 cropping seasons (June-September), we conducted a large number of trials in farmers' fields in the SAT regions of Andhra Pradesh, Karnataka, Madhya Pradesh, and Rajasthan in India with a range of locally important field crops. Each farmer for a crop was treated as a replication. The details of the on-farm trials along with various treatments and crop- and nutrient-management practices followed were similar to those described in Rego et al. (2007).

In the on-farm trials, there were two treatments: (i) control or farmers' nutrient inputs (termed FI) and (ii) balanced nutrient-management treatment (BN) consisting of applications of nutrients found deficient based on soil-test results. The BN treatment consisted of applications of $\mathrm{S}+\mathrm{B}+\mathrm{Zn}$ or SBZn along with $\mathrm{N}$ and $\mathrm{P}$ over the FI treatment [FI + $\mathrm{SBZn}+\mathrm{N}+\mathrm{P}]$. These two treatments were imposed on $2000-$ or $1000-\mathrm{m}^{2}$ plots side by

Table 1

Critical limits in the soil of plant nutrient elements to separate deficient samples from nondeficient samples

\begin{tabular}{lc}
\hline Plant nutrient & Critical limit $\left(\mathrm{mg} \mathrm{kg}^{-1}\right)$ \\
\hline Sodium bicarbonate-extractable P & 5 \\
Ammonium acetate-extractable K & 50 \\
Calcium chloride-extractable S & $8-10$ \\
Hot water-extractable B & 0.58 \\
DTPA-extractable Zn & 0.75 \\
\hline
\end{tabular}

Note. Data are gleaned from various literature sources (for details see Rego et al. 2007; Sahrawat et al. 2007). 
side on the same piece of land. Farmers' crops, crop variety, and crop-management practices were the same in both the treatments. Before implementation of the treatments in the conduct of field trials, the soil-test results on soil samples collected from farmers' fields were shared and discussed with the participating volunteer farmers in their own languages. As mentioned earlier, each farmer's field was considered one replication.

For applying nutrients as per SBZn treatment, we applied S, B, and $\mathrm{Zn}$ via a mixture, which consisted of $200 \mathrm{~kg}$ gypsum $\left(30 \mathrm{~kg} \mathrm{~S} \mathrm{ha}^{-1}\right), 5 \mathrm{~kg}$ borax or $2.5 \mathrm{~kg}$ Agribore $(0.5 \mathrm{~kg}$ $\left.\mathrm{B} \mathrm{ha}{ }^{-1}\right)$ and $50 \mathrm{~kg}$ zinc sulfate $\left(10 \mathrm{~kg} \mathrm{Zn} \mathrm{ha}^{-1}\right) \mathrm{ha}^{-1}$; the mixture was surface broadcast on the plot before the final land preparation. The SBZn $+\mathrm{NP}$ or BN treatment consisted of the same amount of S, B, and Zn as in SBZn plus $60 \mathrm{~kg} \mathrm{~N}$ for cereals or $20 \mathrm{~kg} \mathrm{~N} \mathrm{ha}^{-1}$ for legumes; and $\mathrm{P}$ was added at $30 \mathrm{~kg} \mathrm{P}_{2} \mathrm{O}_{5} \mathrm{ha}^{-1}$. The treatment $\mathrm{SBZn}$ was applied along with P plus $20 \mathrm{~kg} \mathrm{~N} \mathrm{ha}^{-1}$ as basal to all crops and $40 \mathrm{~kg} \mathrm{~N} \mathrm{ha}^{-1}$ was top dressed in the case of cereals. In the case of NP treatment, we applied $20 \mathrm{~kg} \mathrm{~N}$ and $30 \mathrm{~kg} \mathrm{P}_{2} \mathrm{O}_{5} \mathrm{ha}^{-1}$ to all crops as basal and $40 \mathrm{~kg} \mathrm{~N} \mathrm{ha}^{-1}$ as topdressing for cereals.

\section{Results and Discussion}

\section{Organic Carbon and Extractable Nutrient Status of Farmers' Fields}

The soil-test results for $\mathrm{pH}$, organic $\mathrm{C}$, and extractable $\mathrm{P}, \mathrm{K}, \mathrm{S}, \mathrm{B}$, and $\mathrm{Zn}$ of soil samples collected from farmers' fields in the SAT regions of Indian states of Andhra Pradesh (3650 farmers' fields), Karnataka (22867), Madhya Pradesh (341), and Rajasthan (421) showed that the results varied with district in a state and had a wide range in soil chemical fertility parameters (Table 2). In these results, soil organic $\mathrm{C}$ has been used as an index of available N (Sahrawat et al. 2010b).

These first results on the fertility status of farmers' fields at a large scale showed that the samples were generally low in organic $\mathrm{C}$ (we have used soil organic $\mathrm{C}$ as a proxy for $\mathrm{N}$-supplying capacity of a soil), low to medium in Olsen-extractable $\mathrm{P}$, medium to high in exchangeable $\mathrm{K}$, and generally low in calcium chloride-extractable S, hot-waterextractable B, and DTPA-extractable $\mathrm{Zn}$ (Table 2). The results clearly demonstrate that soils are not only low in organic $\mathrm{C}$ and Olsen $\mathrm{P}$ but also low in secondary nutrients such as $\mathrm{S}$ and micronutrients such as $\mathrm{B}$ and $\mathrm{Zn}$. The number of farmers' fields sampled from 14 districts of Karnataka State was fairly large and based on the results of these samples; some plausible conclusions can be drawn for the prevalence of plant nutrient problems in the state, which is the second largest state in India with rainfed agriculture after Rajasthan. The mean organic $\mathrm{C}$ content in the soil samples was $0.45 \%$, Olsen $\mathrm{P}$ was deficient in $47 \%$ of the 22,867 farmers' fields sampled, deficiencies were as follows: exchangeable $\mathrm{K}$ in $16 \%$ of farmers' fields, extractable S in $83 \%$ of fields, hot-water-extractable B in $66 \%$ of fields, and DTPA-extractable $\mathrm{Zn}$ in $61 \%$ of fields.

In Andhra Pradesh, B deficiency was most prevalent (in $85 \%$ of the 3650 fields sampled), followed by $\mathrm{S}$, which was deficient in $79 \%$ of fields, and $\mathrm{Zn}$, which was deficient in $69 \%$ of fields). Olsen P was deficient in $38 \%$ of the fields and K only in $12 \%$ of the fields (Table 2). In Madhya Pradesh (341 farmers' fields sampled), B deficiency was most prevalent (79\% of fields), followed by S (74\%), Olsen P (74\%), and Zn (66\%). In Rajasthan (421 fields sampled), the deficiency of $\mathrm{S}$ was most widespread (71\% of fields), followed by B (56\%), Olsen P (45\%), Zn (40\%), and K (15\%) (Table2).

Considering the results of analyses of all soil samples from the four states in the SAT region of India, it can be concluded that the deficiency of S (calcium chloride extractable) was most widespread (on an average $82 \%$ of the 28,270 farmers' fields sampled were 


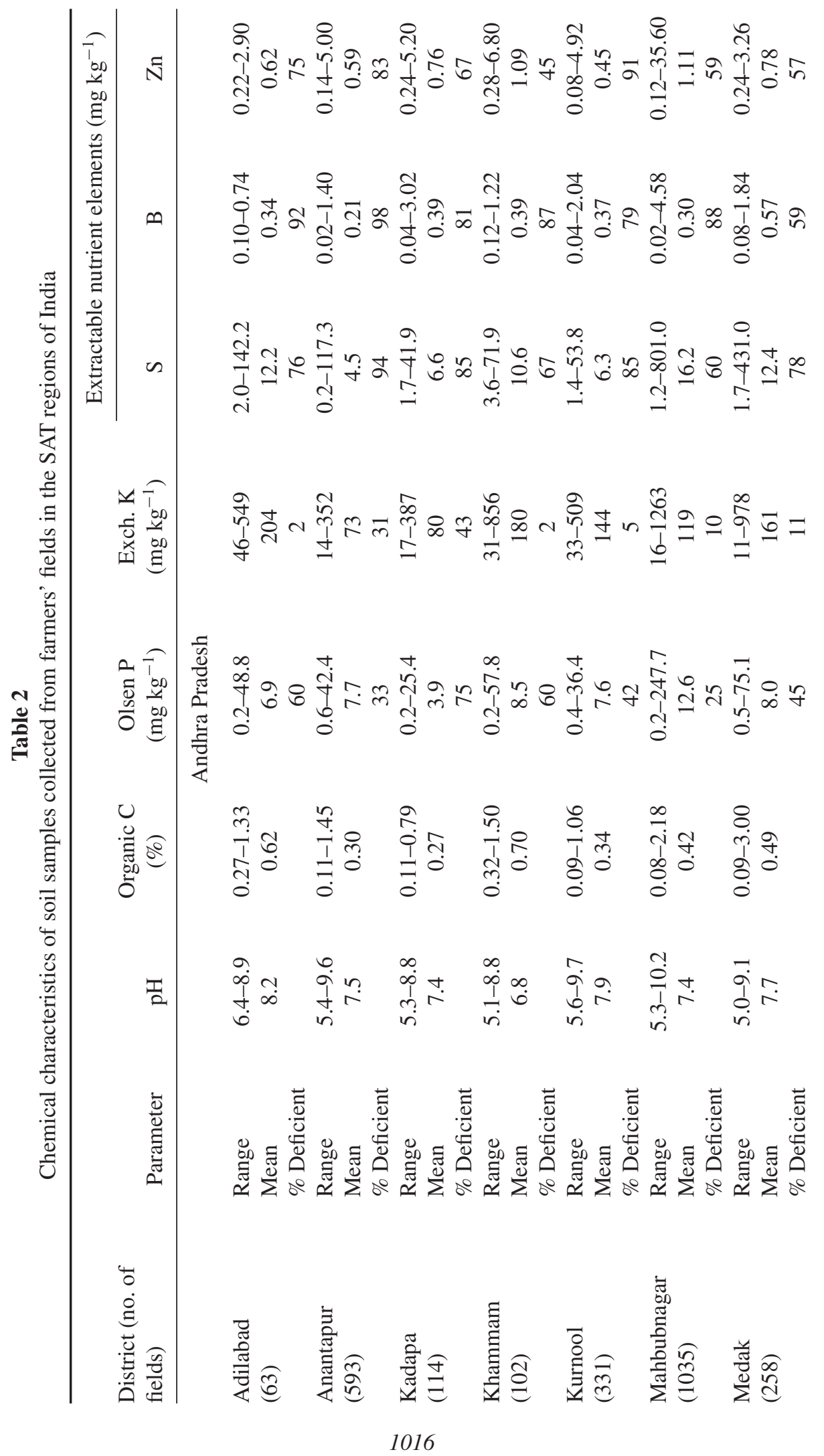


8

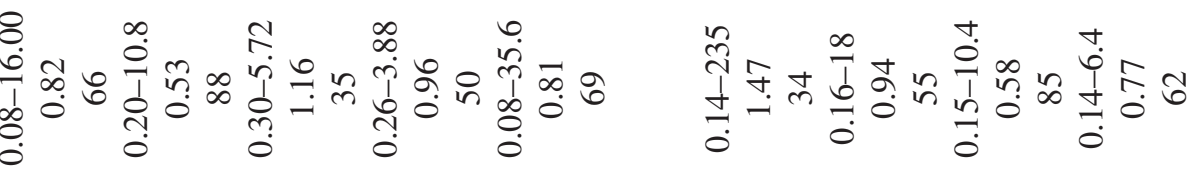

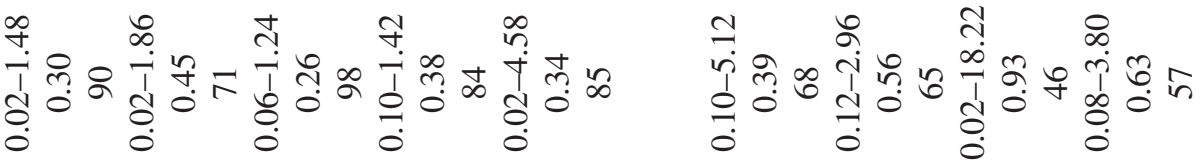

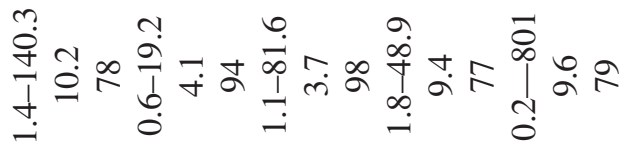

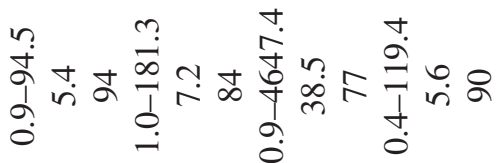

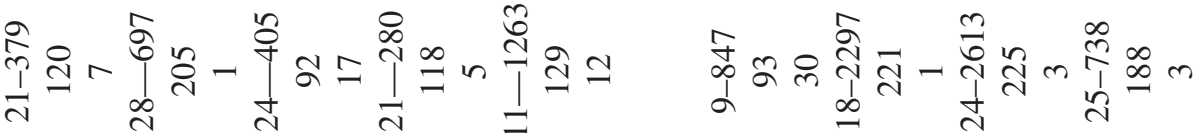

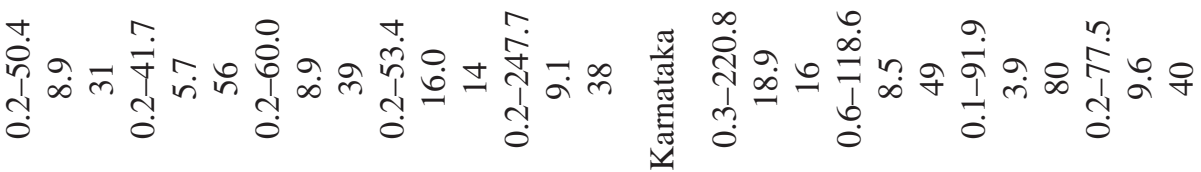

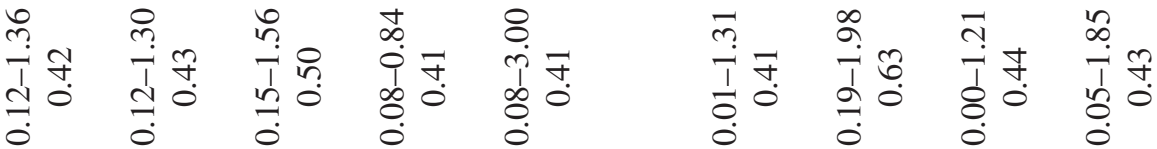

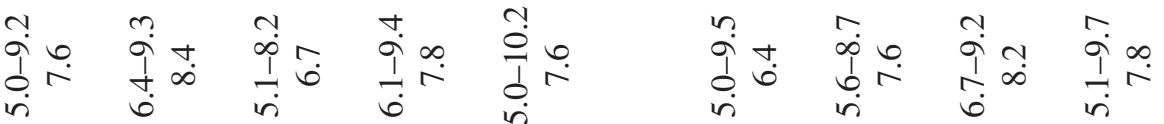

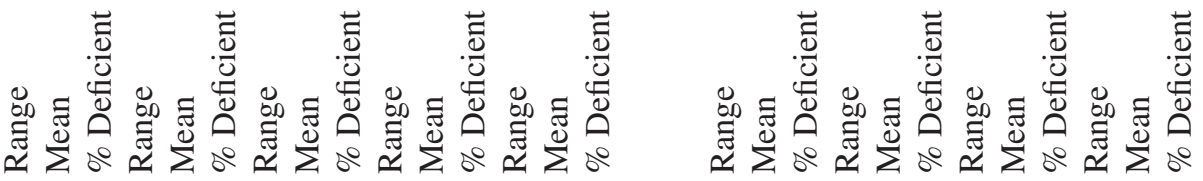

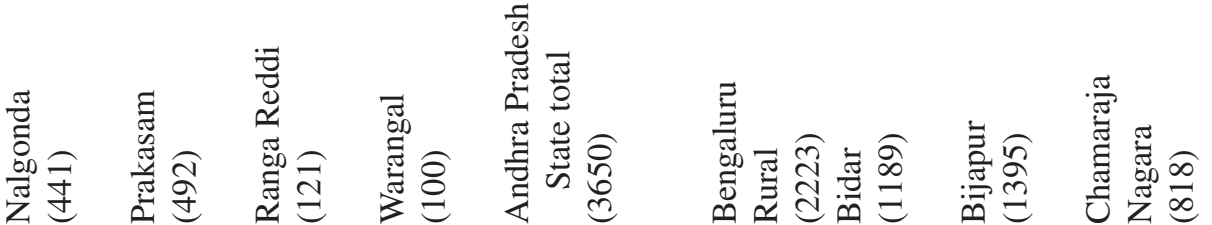




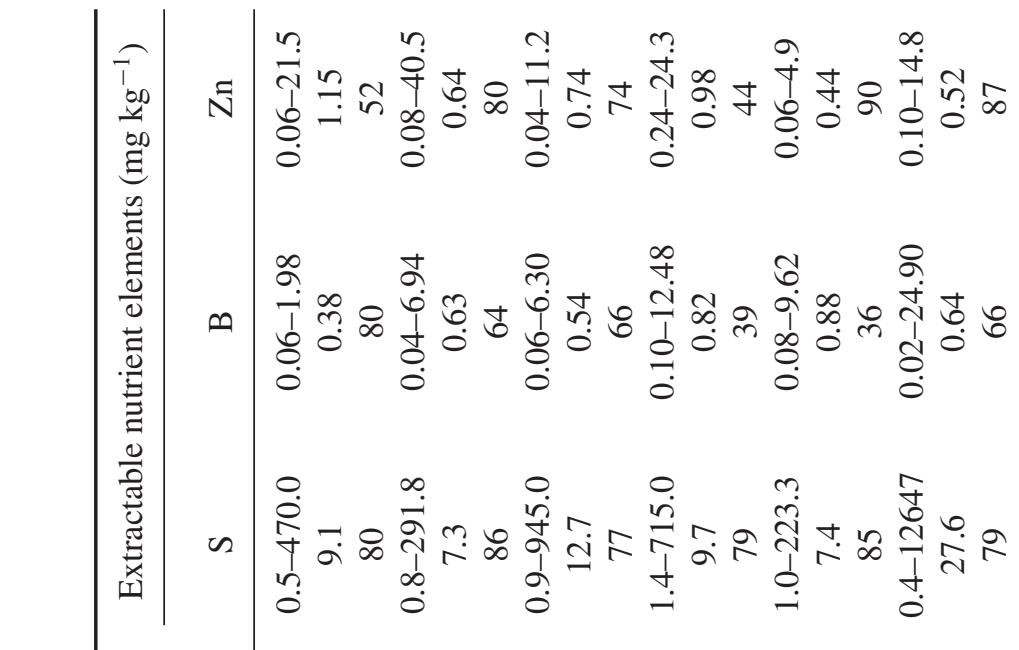

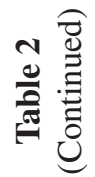

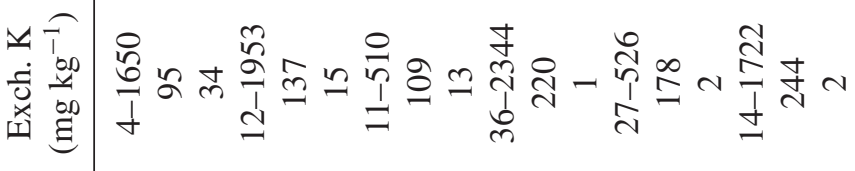

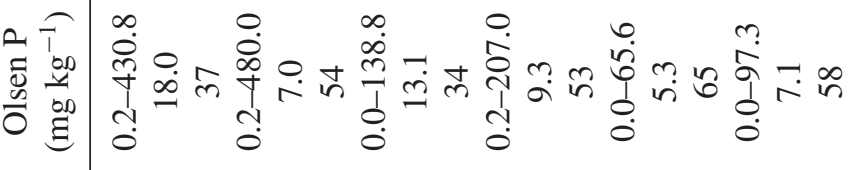

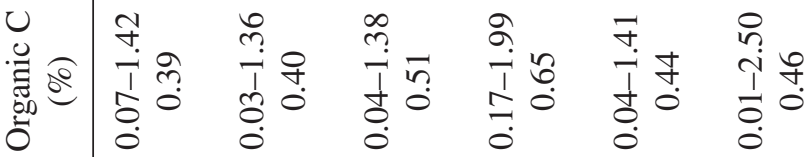

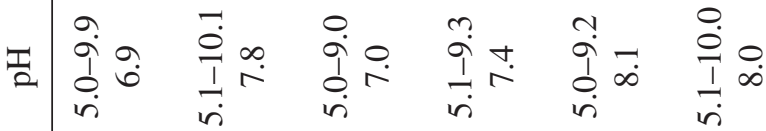

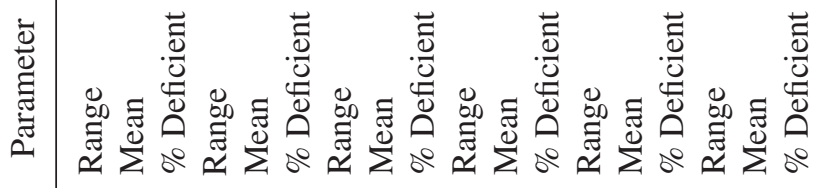

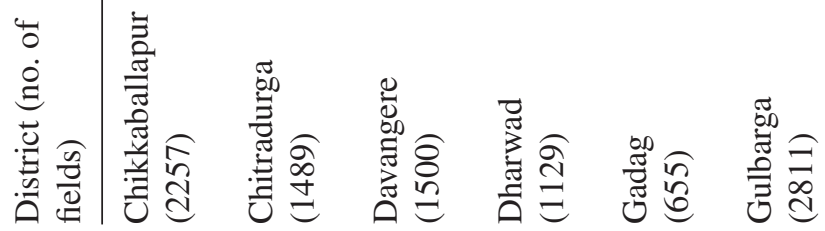




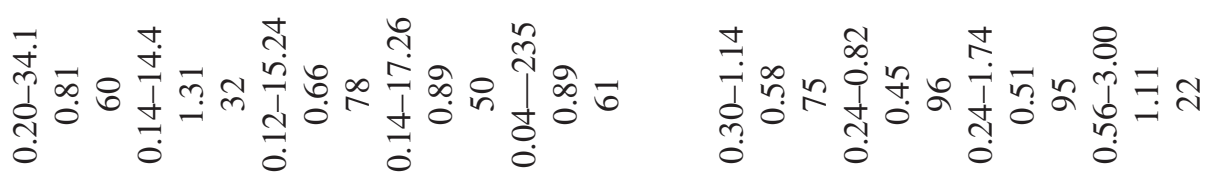

$\begin{array}{llllll}0 & 0 \\ 0 & 0 & 0 & 0 & 0 \\ 0 & 0 & 0 & 0\end{array}$

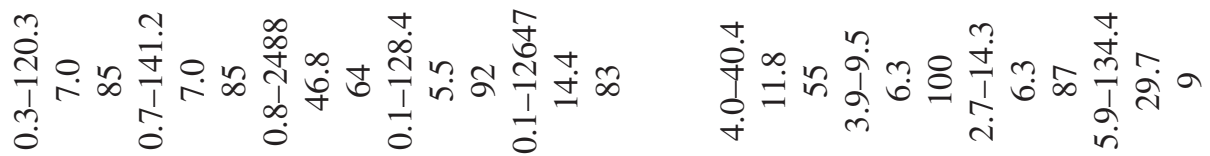

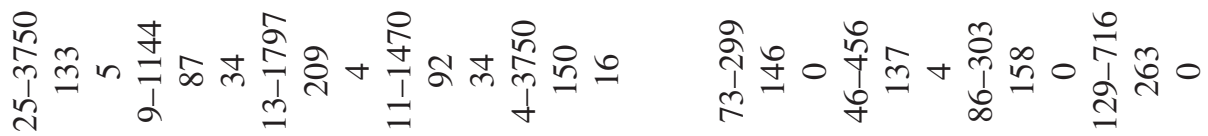

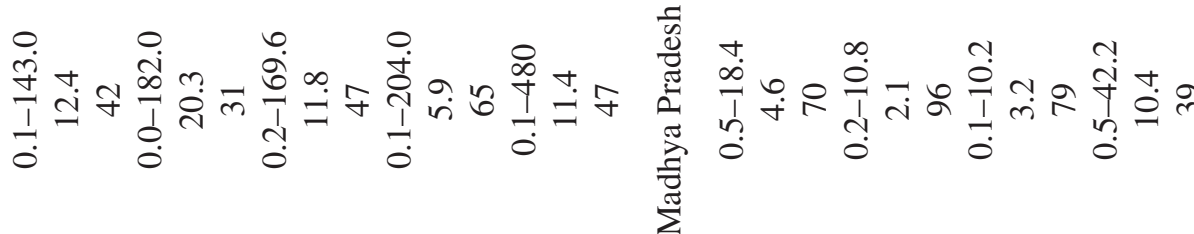

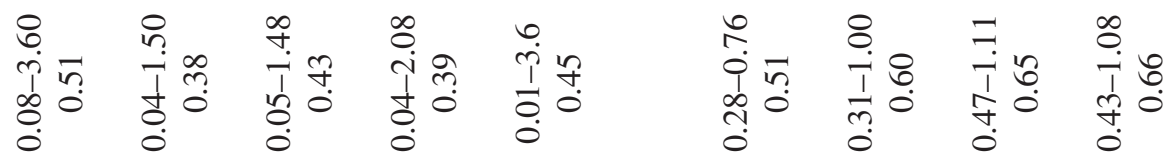

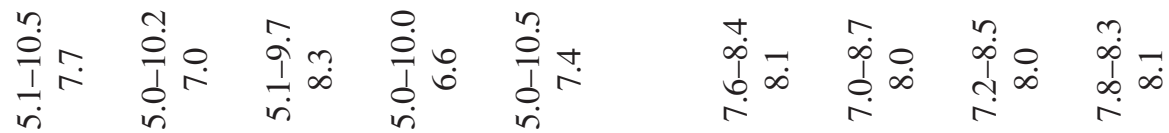

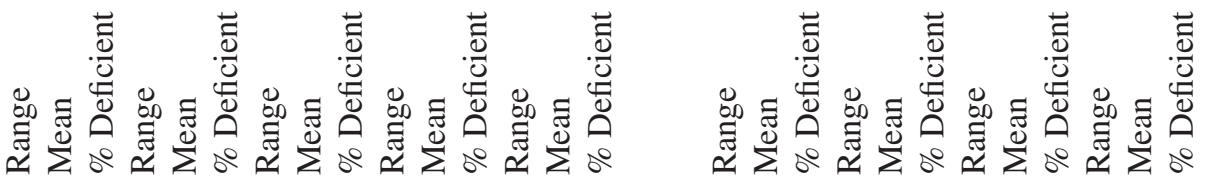

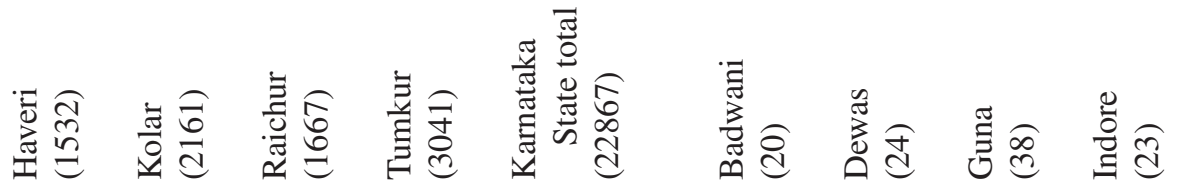




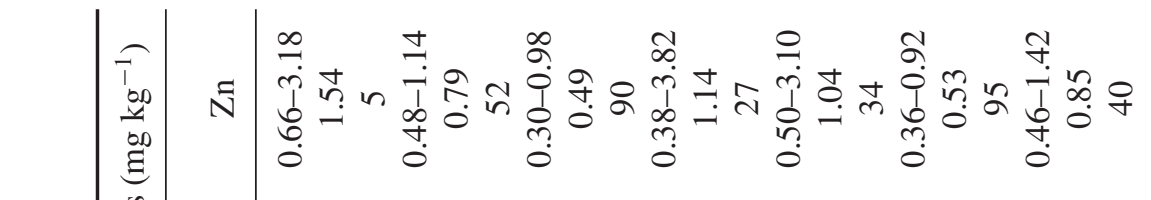

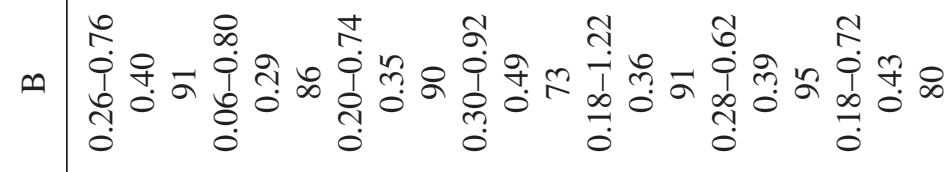

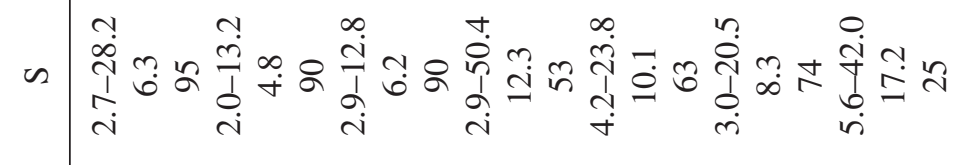

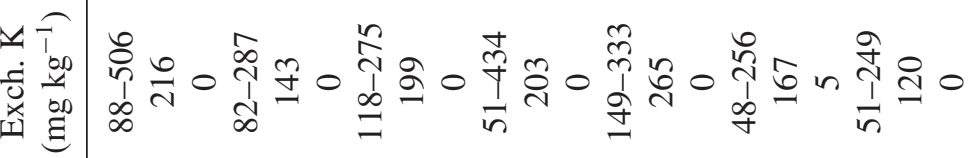

$$
\begin{aligned}
& \text { 吾 }
\end{aligned}
$$

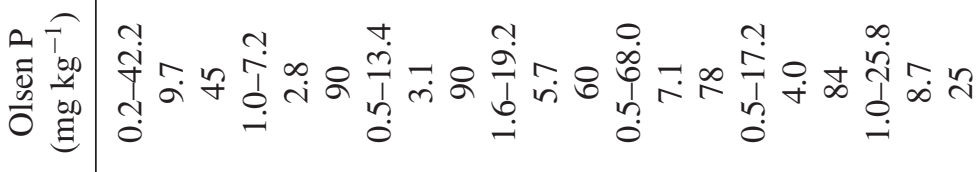

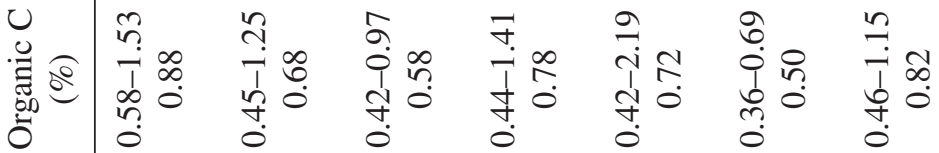

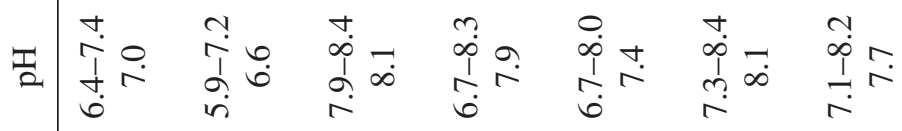

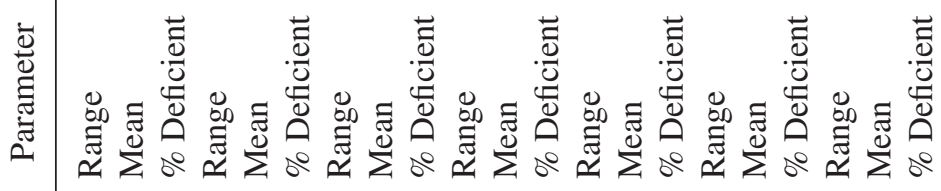

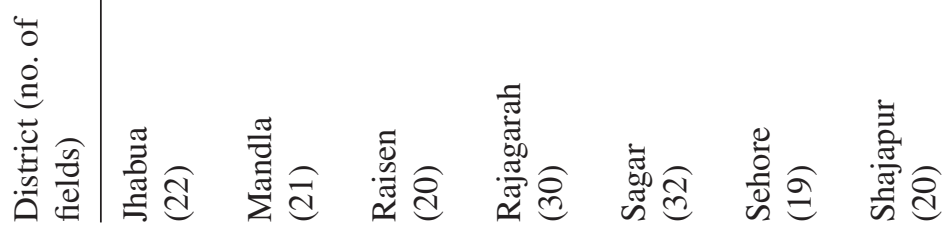




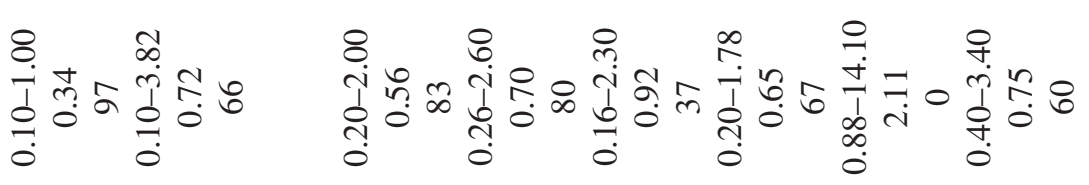

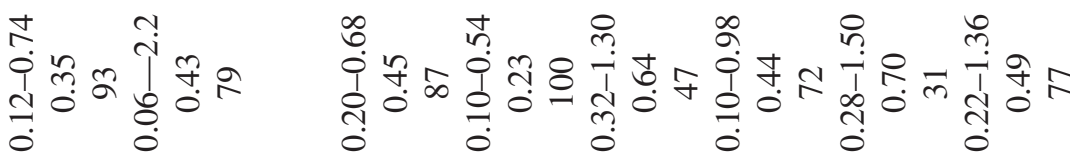

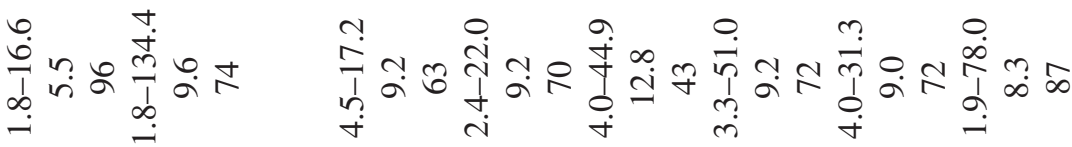

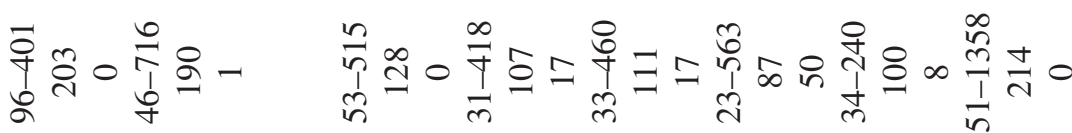

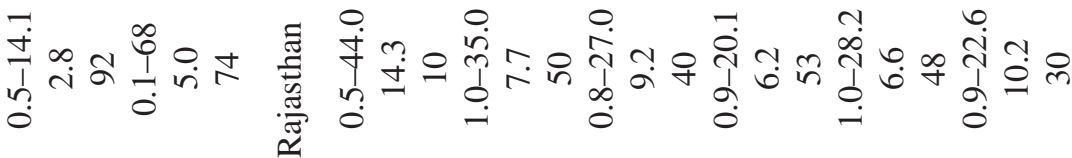

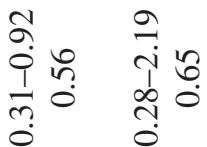

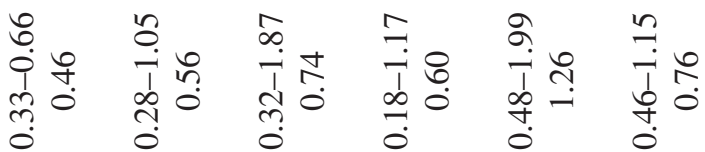

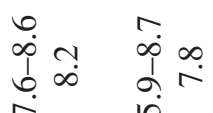

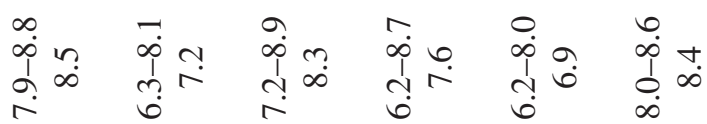

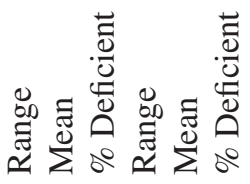

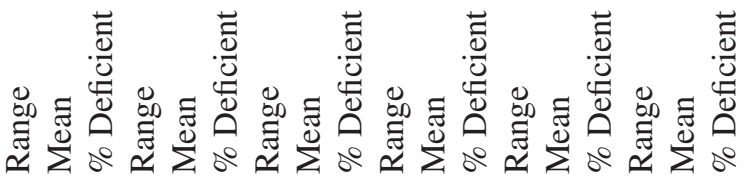

焉

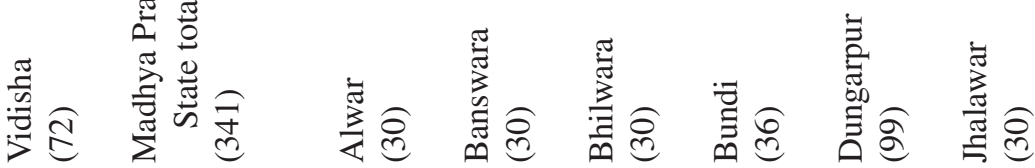




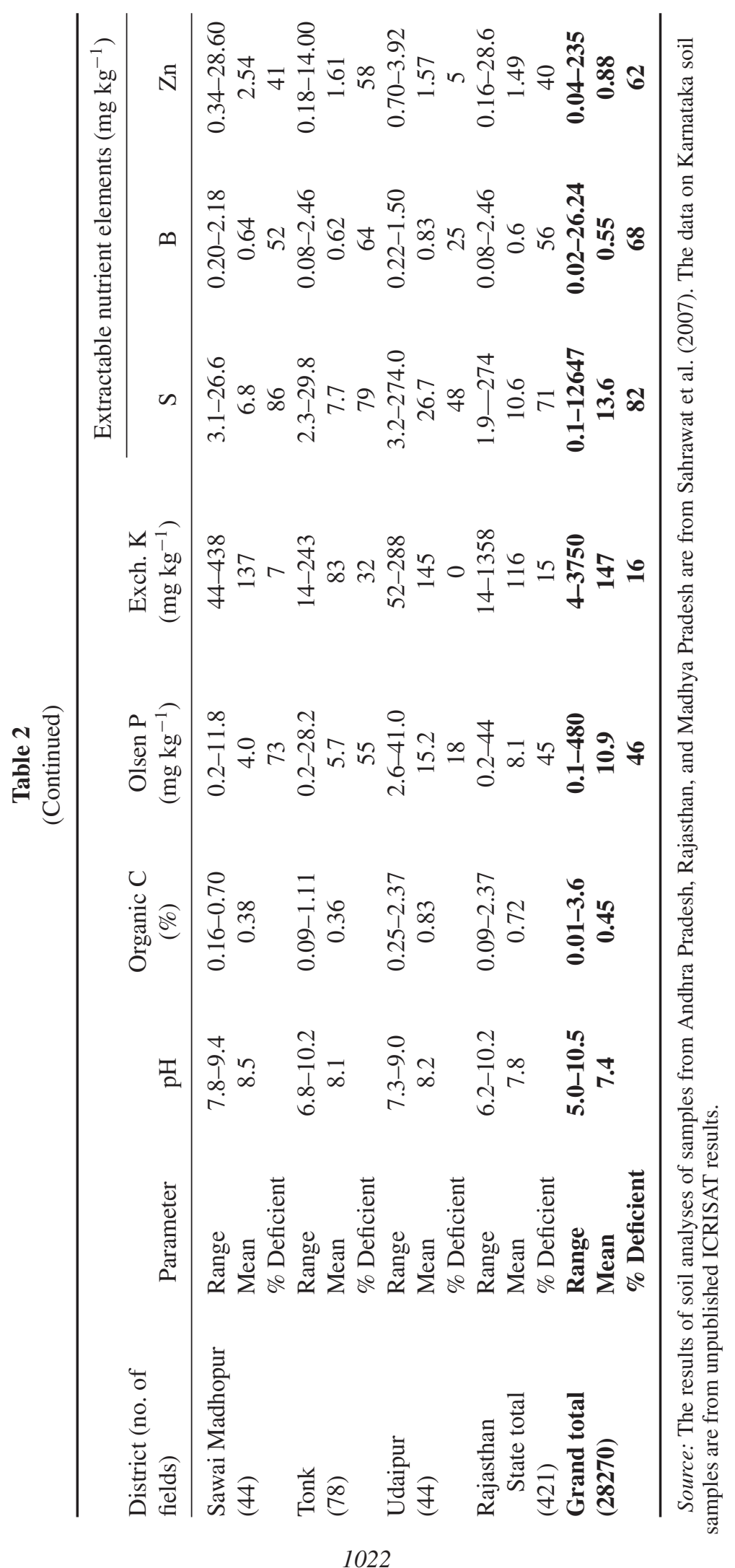


deficient), followed by hot-water-extractable B (68\% of the farmers' fields sampled were deficient) and DTPA-extractable Zn (62\% of the farmers' fields were deficient); and the finding is revealing. These results are in accord with those reported earlier with a limited number of soil samples (Rego et al. 2005; Sahrawat et al. 2007, 2010b).

Another important finding emerging from the soil-test results is that $\mathrm{K}$ deficiency has not emerged as a prominent nutrient deficiency, as on average only $16 \%$ of the farmers' fields out of a total of 28,270 farmers' fields sampled were deficient in the rainfed production systems of the SAT regions (Table 2).

These results are significant in showing the widespread nature of the deficiencies of major nutrients such as $\mathrm{N}$ and $\mathrm{P}$, but more importantly those of $\mathrm{S}, \mathrm{B}$, and $\mathrm{Zn}$ in the rainfed production systems of the SAT in India. The extent of deficiencies of plant nutrients appear as widespread as those reported from the intensified irrigated systems (Pasricha and Fox 1993; Takkar 1996; Scherer 2001; Fageria, Baligar, and Clark 2002; Sahrawat et al. 2010b). To our knowledge, no relatively large-scale on-farm survey of the nutrient status of farmers' fields in the SAT regions of India has been undertaken and thus no benchmark results are available to compare the extent of the deficiencies of $\mathrm{S}$ and micronutrients in farmers' fields. These results do clearly demonstrate that in addition to water stress, multiple-nutrient deficiencies have to be managed to unlock the potential of rainfed production systems. The earlier research on fertility management has mostly concentrated on the major nutrients, and the deficiencies of $\mathrm{N}$ and $\mathrm{P}$ have been reported to be widespread in the rainfed systems (El-Swaify et al. 1985; Sahrawat, Abekoe, and Diatta 2001; Rego et al. 2003; Bationo et al. 2008).

Depletion of soil organic matter and major plant nutrients $(\mathrm{N}, \mathrm{P}$, and $\mathrm{K}$ ) remains a major constraint to long-term agricultural sustainability in much of the rainfed agricultural systems in the SAT regions of Asia and sub-Saharan Africa. Negative nutrient balances (nutrient added minus nutrient harvested in crop) relative to mostly major plant nutrients have been reported, as the nutrient removal exceeds input over a long period of time with concomitant decline in soil organic-matter status. Organic-matter depletion problem is particularly acute in the rainfed systems where the external inputs of organic matter and nutrients are far lower than the loss or removal (Katyal 2003; Rego et al. 2003; Bationo et al. 2008; Bekunda, Sanginga, and Woomer 2010).

\section{Soil-Test-Based Nutrient Management: Effects on Crop Productivity and Quality}

As mentioned in the introduction, soil-fertility-management research in the rainfed areas has focused mainly on the management of major nutrients $(\mathrm{N}, \mathrm{P}$, and $\mathrm{K}$ ) and even the amounts of these nutrients are generally inadequate (Rego et al. 2007; Bationo et al. 2008; Sahrawat et al. 2010b). Water stress from erratic and low rainfall is the major bottleneck for farmers to apply adequate amounts of nutrients in the rainfed systems. However, recent work by ICRISAT and its partners and other researchers has shown that for realizing the potential of rainfed systems, both water stress and nutrient deficiencies need to be attended simultaneously (Wani et al. 2003; Ncube et al. 2007; Bationo et al. 2008; Sahrawat et al. 2010a).

Rego et al. (2007) conducted a number of on-farm trials under rainfed conditions for 3 years (2002-2004) during the rainy season (June-October) in three districts of Andhra Pradesh in the SAT region of India to evaluate crop responses to balanced nutrient management based on soil-test results using mung bean, maize, groundnut, castor, and pigeonpea. There were two treatments, (i) control or farmer's nutrient input (FI) and (ii) balanced nutrient (BN) management, which consisted of the applications of SBZn + NP over FI or 


\section{Table 3}

Gain yields of crops in response to fertilization according to farmer's inputs (FI) and balanced nutrient management $(\mathrm{BN}, \mathrm{BN}=\mathrm{FI}+\mathrm{SBZn}+\mathrm{NP})$ treatments in the semi-arid zone of Andhra Pradesh, India, during three (2002 to 2004) rainy seasons

\begin{tabular}{ccccccc}
\hline & & \multicolumn{5}{c}{ Grain yield $\left(\mathrm{kg} \mathrm{ha}^{-1}\right)$} \\
\cline { 3 - 6 } Year & Treatment & Maize & Castor & Mung bean & Groundnut (pod) & Pigeonpea \\
\hline 2002 & FI & $2730(20)^{a}$ & $590(8)$ & $770(9)$ & $1180(19)$ & $536(43)$ \\
& BN & 4560 & 880 & 1110 & 1570 & 873 \\
& LSD (0.05) & 419 & 143 & 145 & 92 & 156 \\
2003 & FI & $2790(24)$ & $690(17)$ & $900(6)$ & $830(30)$ & $720(12)$ \\
& BN & 4880 & 1190 & 1530 & 1490 & 1457 \\
2004 & LSD (0.05) & 271 & 186 & 160 & 96.8 & 220 \\
& FI & $2430(19)$ & $990(6)$ & $740(12)$ & $1320(40)$ & $1011(21)$ \\
& BN & 4230 & 1370 & 1160 & 1830 & 1564 \\
& LSD (0.05) & 417 & 285 & 131 & 122.5 & 106 \\
\hline
\end{tabular}

Source: The results on maize, castor, mung bean, and groundnut crops are from Rego et al. (2007), and the data on pigeonpea crop are from ICRISAT unpublished results.

${ }^{a}$ The values in parentheses are the number of farmers' fields used for on-farm trials.

FI + SBZn + NP. The grain yields of maize, castor, mung bean, groundnut (pod yield), and pigeonpea crops were significantly increased under BN with the applications of SBZn + NP over the FI treatment in the three seasons (Table 3).

A large number of on-farm trials were also conducted in the semi-arid zone of Karnataka state during five rainy seasons (2005-2009) with maize, finger millet, groundnut, and soybean as the test crops. Again, as in the case of trials in Andhra Pradesh, $\mathrm{BN}$ treatment significantly increased the grain yields of these crops over the farmer's inputs treatment (Table 4). In another set of trials, conducted during 2005-2007 in the semi-arid zone of Karnataka, BN significantly increased maize grain yield and dry matter over the farmer's inputs treatment and significantly improved the harvest index of the crop during all the three seasons (Rajashekhara Rao et al. 2010).

The results of on-farm trials conducted in the SAT zone of Madhya Pradesh with soybean in the 2008 and 2009 rainy season and chickpea in the 2008-2009 post-rainy seasons confirmed the superiority of the BN treatment over the FI treatment and significantly increased soybean and chickpea grain yields (Table 5). Similar results were obtained in the on-farm trials conducted during the 2008 rainy season in the semi-arid zone of Rajasthan, India, with pearl millet and maize as the test crops, and the grain yields of these crops were significantly increased in the BN treatment as compared to FI (Table 6).

On-farm trials were conducted during the 2006-2007 seasons with a number of vegetable crops in watersheds in three districts (Dharwad, Haveri, and Chitradurga) of Karnataka to study their responses to BN management as compared to FI treatment. The results showed an impressive yield response to BN management as compared to FI treatment, and the growth of vegetables under BN management was economically viable and remunerative (Srinivasarao et al. 2010).

Balanced plant nutrition is not only important for increasing crop productivity but also critical for enhancing crop quality, including grain and stover/straw quality, which has implications for human (grain as food) and animal (straw used as fodder or feed) nutrition. There is a relationship between soil health and food and feed quality, which in turn 
Table 4

Grain yields of crops in response to fertilization according to farmer's inputs (FI) and balanced nutrient management $(\mathrm{BN}, \mathrm{BN}=\mathrm{FI}+\mathrm{SBZn}+\mathrm{NP})$ treatments in the semi-arid zone of Karnataka, India, during five (2005 to 2009) rainy seasons

\begin{tabular}{lccccc}
\hline \multirow{2}{*}{ Year } & & \multicolumn{4}{c}{ Grain yield $\left(\mathrm{kg} \mathrm{ha}^{-1}\right)$} \\
\cline { 3 - 5 } 2005 & Treatment & Maize & Finger Millet & Groundnut & Soybean \\
\cline { 3 - 5 } & FI & $4000(6)^{a}$ & $2100(16)$ & $1830(8)$ & $2030(6)$ \\
2006 & BN & 6090 & 3280 & 1910 & 3470 \\
& LSD $(0.05)$ & 395 & 338 & 91.5 & 664 \\
& FI & $4050(22)$ & $1700(17)$ & $1080(17)$ & $1120(7)$ \\
2007 & BN & 5400 & 2170 & 1450 & 2650 \\
& LSD $(0.05)$ & 240 & 440 & 341.4 & 538 \\
2008 & FI & $5670(19)$ & $2000(27)$ & $1310(23)$ & $2120(11)$ \\
& BN & 8710 & 2940 & 2160 & 3120 \\
& LSD (0.05) & 572 & 230 & 191.4 & 262 \\
2009 & FI & $4400(27)$ & $1680(152)$ & $940(149)$ & $1390(16)$ \\
& BN & 6130 & 2650 & 1430 & 1640 \\
& LSD $(0.05)$ & 336 & 125 & 80.3 & 249 \\
& FI & $5460(90)$ & $1630(165)$ & $1100(178)$ & $1770(36)$ \\
& BN & 7800 & 2570 & 1500 & 2610 \\
& LSD (0.05) & 178 & 91 & 49.9 & 184 \\
\hline
\end{tabular}

Source: Unpublished results from ICRISAT.

${ }^{a}$ The values in parentheses are the number of farmers' fields used for on-farm trials.

Table 5

Grain yields of soybean (rainy season) and chickpea (post-rainy season) in response to fertilization according to farmer's inputs (FI) and balanced nutrient management (BN, BN $=\mathrm{FI}+\mathrm{SBZn}+\mathrm{NP}$ ) treatments in Madhya Pradesh, India, during 2008 and 2008-2009 seasons

\begin{tabular}{lccc}
\hline & & \multicolumn{2}{c}{ Grain yield $\left(\mathrm{kg} \mathrm{ha}^{-1}\right)$} \\
\cline { 3 - 4 } Year & Treatment & Soybean & Chickpea \\
\hline 2008 & FI & $1490(117)^{a}$ & $1250(169)$ \\
& BN & 1840 & 1440 \\
2009 & LSD (0.05) & 56 & \\
& FI & $2120(140)$ & \\
& BN & 2680 & \\
\hline
\end{tabular}

Source: Unpublished results from ICRISAT.

${ }^{a}$ The values in parentheses are the number of farmers' fields used for on-farm trials.

impacts human and animal health. The importance of mineral nutrition of crops along with improved cultivars of crops and crop management cannot be overemphasized for producing nutritious food (Graham et al. 2007; Parthasarathy Rao et al. 2006; Sahrawat et al. 2008a) and fodder (Kelly et al. 1996; Sahrawat et al. 2008a; Rattan et al. 2009). 


\section{Table 6}

Yields of maize and pearl millet in response to fertilization according to farmer's inputs (FI) and balanced nutrient management $(\mathrm{BN}, \mathrm{BN}=\mathrm{FI}+\mathrm{SBZn}+\mathrm{NP})$ treatments in the semi-arid zone of Rajasthan, India, during the 2008 rainy season

\begin{tabular}{lccc}
\hline & & \multicolumn{2}{c}{ Grain yield $\left(\mathrm{kg} \mathrm{ha}^{-1}\right)$} \\
\cline { 3 - 4 } Year & Treatment & Maize & Pearl millet \\
\hline 2008 & FI & $2730(17)^{a}$ & $2310(16)$ \\
& BN & 2980 & 2510 \\
& LSD $(0.05)$ & 55 & 34.3 \\
\hline
\end{tabular}

Source: ICRISAT unpublished results.

${ }^{a}$ The values in parentheses are the number of farmers' fields used for on-farm trials.

For example, in the on-farm experiments conducted to determine the effects of $\mathrm{S}$, $\mathrm{B}$, and $\mathrm{Zn}$ fertilization on the grain and straw quality of sorghum and maize grown under rainfed conditions in the SAT region of India showed that the $\mathrm{BN}$, through combined application of S, B, Zn, N, and P, as compared to the FI increased N, S, and Zn concentrations in the grain and straw of these crops (Sahrawat et al. 2008a). These results stress the importance of balanced mineral nutrition of crops for increased produce quality. For example, the $\mathrm{S}$ fertilization of oilseed crops such as soybean, canola, and sunflower not only is required for increasing dry matter and seed yield but also essential for enhancing oil concentration and quality (Saha et al. 2001; Usha Rani et al. 2009; Brennan et al. 2010).

From this discussion on the results obtained in on-farm trials, it is evident that in the SAT region multiple nutrient deficiencies, especially of $\mathrm{N}, \mathrm{P}, \mathrm{S}, \mathrm{B}$, and $\mathrm{Zn}$, are holding back the potential of rainfed systems and are also responsible for low rainwater-use efficiency in rainfed areas in the SAT regions (Singh et al. 2009). Also, soil fertility depletion has been recognized as the major biophysical cause of declining food availability in smallholder farms in sub-Saharan Africa. It was suggested that any program aimed at reversing the trend in declining agricultural productivity and food quality and preserving the environmental quality must begin with soil fertility restoration and maintenance. The decline in productivity is related to decline in soil fertility, which in turn is directly related to decline in soil organic-matter status and depletion of the plant nutrient reserves in various production systems with little or no investment in recuperating soil fertility in agroecosystems (Sanchez et al. 1997; Bationo et al. 2008; Lal 2008; Bekunda, Sanginga, and Woomer 2010).

Soil fertility maintenance is not only a prerequisite for sustainable increase in crop productivity but is equally essential for maintaining crop quality in terms of food, fodder, and feed quality (Kelly et al. 1996; Sahrawat et al. 2008a), especially iron (Fe) and $\mathrm{Zn}$ in the grain (Graham et al. 2007; Sahrawat et al. 2008a; Rattan et al. 2009). The results from onfarm studies also show that the productivity of the rainfed systems can be enhanced through management of various nutrient deficiencies. It is demonstrated from the results of a large number of on-farm trials conducted in different parts of India that with soil-test-based BN management productivity in rainfed areas can be increased by harnessing the potential of rainfed agriculture. Unless the constraints on soil fertility management are alleviated, it would not be possible to achieve the potential productivity of the rainfed systems. Because the area under rainfed production is very large, even a modest sustainable increase in yield would contribute significantly to the global food pool, apart from providing income to the rural poor. 
For practical utilization of the soil-test-based nutrient management, we have used the GIS-based extrapolation methodology to map the deficiencies of nutrients, especially $\mathrm{S}, \mathrm{B}$, and $\mathrm{Zn}$, in various districts in Karnataka State, India (ICRISAT, unpublished results). The soil-test-based fertilizer application has been put online so that the recommendations can be downloaded and made available to farmers using color codes depicting the deficiency or sufficiency of a nutrient. Such information can be easily used by smallhold farmers. Typical examples of nutrient mapping for extractable (available) S, B, and Zn, using data from selected districts of Karnataka, are shown in Figure 1. Such maps can be extended and used by farmers in a cluster of villages to plan the application of deficient nutrients to production systems.

\section{Discussion and Conclusions}

It is recognized that water-related plant stress is the primary constraint to crop production and productivity in the rainfed systems in the SAT, and consequently the importance of water shortage has globally been rightly emphasized (Wani et al. 2002, 2003; CAWMA 2007; Pathak et al. 2009). However, apart from water shortage, there is the issue of severe soil infertility problems in the rainfed systems (Rego et al. 2007; Sahrawat et al. 2010b; Bekunda, Sanginga, and Woomer 2010) and managing water stress alone cannot sustainably enhance the productivity of rainfed systems. Hence for achieving sustainable gains in rainfed productivity both water shortage and soil fertility problems need to be simultaneously addressed through effective natural resource management (Wani et al. 2009; Sahrawat et al. 2010a).

For the first time, a large number of farmers' fields in the SAT regions of India were sampled and analyzed for organic $\mathrm{C}$ and extractable or available nutrients in an effort to diagnose the prevalence of major and micronutrient deficiencies. The results on the analyses of 28,270 soil samples from the farmers' fields (Table 2) demonstrate that the soils in rainfed areas are indeed infertile and not only deficient in major nutrients, especially $\mathrm{N}$ (soil organic $\mathrm{C}$ status used as an index for available $\mathrm{N}$ ) and $\mathrm{P}$, but also low in organicmatter reserve. The most revealing results, however, were the widespread nature of the deficiencies of S, B, and Zn (Rego et al. 2007; Sahrawat et al. 2007, 2010b).

A summary of results of on-farm responses of several field crops to applications of deficient nutrients together with $\mathrm{N}$ and $\mathrm{P}$ demonstrated that $\mathrm{BN}$ management has potential to significantly enhance the productivity of a range of crops and improve grain and straw quality in the SAT regions under rainfed conditions.

It would appear from these results that soil-test-based nutrient-management approach may be an important entry point activity and also a mechanism to diagnose and manage soil fertility in practical agriculture (Wani 2008). Soil and plant tests have long been used as tools to diagnose and manage soil fertility problems in the intensified irrigated systems and commercial crops including fruit and vegetable crops to maximize productivity (Dahnke and Olson 1990; Mills and Jones 1996; Black 1993; Reuter and Robinson 1997). However, soil testing has not been used to diagnose and manage nutrient problems in farmers' fields in the SAT regions at a scale reported in this article. The critical limits for P, K, S, B, and Zn in the soil (Table 1) seem to provide a fair basis for separating deficient soils from those that are not deficient. Soils below the critical limits of the nutrients evaluated responded to the applications of nutrients; although the overall crop response was regulated by the rainfall received during the cropping season (Rego et al. 2007; Sahrawat et al. 2007, 2010b). Soiltest-based nutrient application also allows judicious and efficient use of nutrient inputs at the local and regional levels (Black 1993; Sahrawat et al. 2010b). 

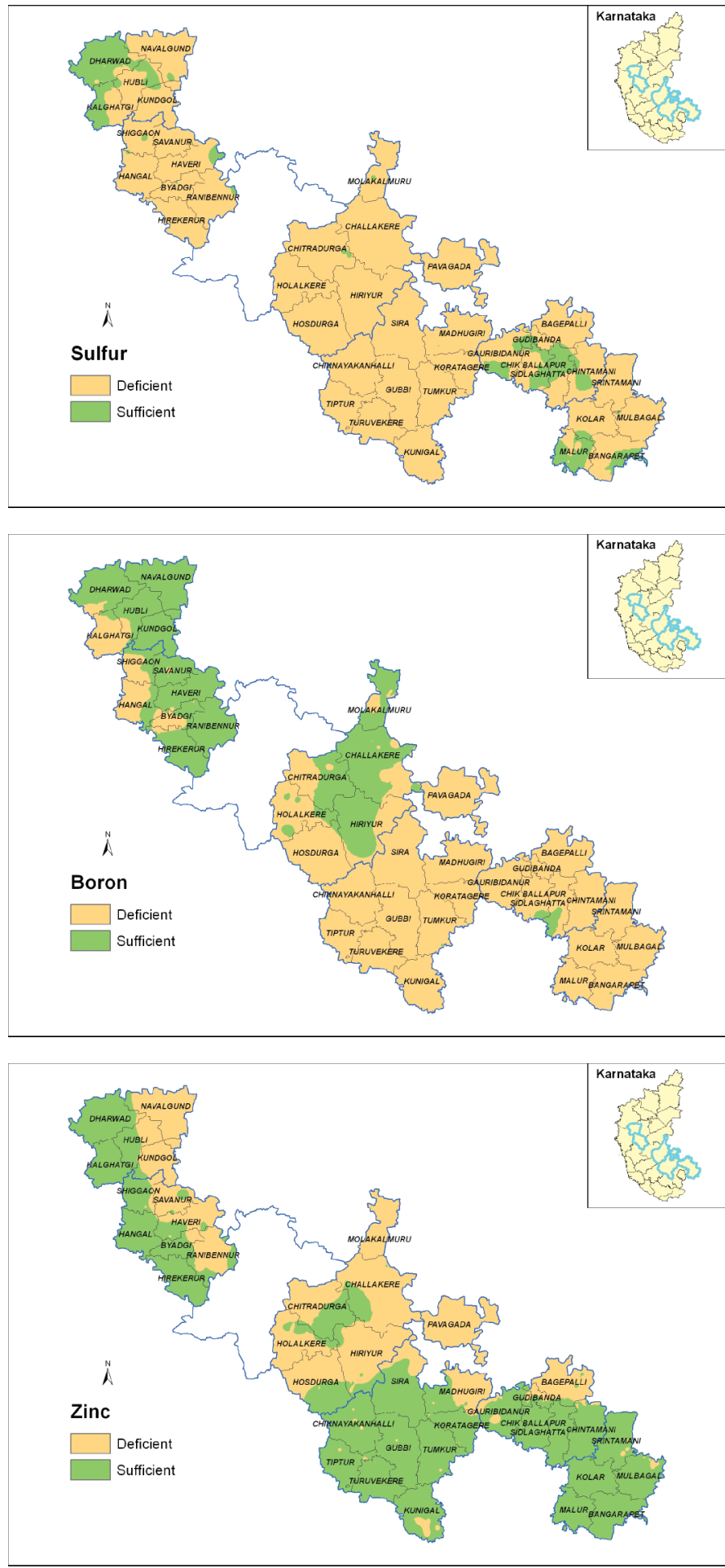

Figure 1. Distribution of extractable sulfur, boron, and zinc in soil samples from various districts of Karnataka. (color figure available online). 
For more widespread adoption and use of soil testing for the diagnosis and management of plant nutrient deficiencies in the rainfed systems of the SAT regions, there is need to strengthen the soil-testing facilities at the local and regional levels for science-based management and maintenance of soil fertility, a prerequisite for sustainable increase in productivity of the rainfed systems (Sahrawat et al. 2007; 2010b). We do hope that the research reported here would stimulate research for widespread use of soil testing as a means for soil-fertility management in farmers' fields.

For enhancing the overall agricultural productivity and crop quality of the rainfed systems, the choice of crops and adapted cultivars along with soil-, water-, and nutrientmanagement practices need to be integrated at the farm level (Wani et al. 2009; Sahrawat et al. 2010b). To achieve this, research and extension support and increased capacity of all the stake holders need to converge (Sahrawat et al. 2010b; Wani 2008). Indeed, ICRISAT and its research partners most appropriately advocate the integration of genetics (crops and its cultivars, social aspects) and natural-resource management for technology targeting and greater impact of agricultural research in the SAT (Twomlow et al. 2008). The strategy is based on the use of crop cultivars that are adapted to the harsh conditions of the SAT regions, especially water stress and nutrient deficiencies. The soil-, water-, and nutrientmanagement practices are developed around the adapted cultivars to realize the potential of the cultivars in diverse production systems (Ae et al. 1990; Condon et al. 2004; Hiradate et al. 2007; Passioura 2006; Bationo et al. 2008; Sahrawat 2009; Passioura and Angus 2010).

\section{Acknowledgments}

We thank the Andhra Pradesh Rural Livelihood Program of the government of Andhra Pradesh, the Department for International Development (DFID, UK), the World Bank Special Fund for Watershed Development, the government of Karnataka, and the Sir Dorabji Tata Trust for financial support. We are also thankful to all farmers who participated in these studies.

\section{References}

Ae, N., J. Arihara, K. Okada, T. Yoshihara, and C. Johansen. 1990. Phosphorus uptake by pigeon pea and its role in cropping systems of the Indian subcontinent. Science 248:477-480.

Bationo, A., J. Kihara, B. Vanlauwe, J. Kimetu, B. S. Waswa, and K. L. Sahrawat. 2008. Integrated nutrient management: Concepts and experience from sub-Saharan Africa. In Integrated nutrient management for sustainable crop production, ed. M. S. Aulakh and C. A. Grant, 467-521. New York: Haworth Press.

Bekunda, M., N. Sanginga, and P. L. Woomer. 2010. Restoring soil fertility in sub-Saharan Africa. Advances in Agronomy 108:183-286.

Black, C. A. 1993. Soil fertility evaluation and control. Boca Raton, Fl.: Lewis Publishers.

Brennan, R. F., R. W. Bell, C. Raphael, and H. Eslick. 2010. Sources of sulfur for dry matter, seed yield, and oil concentration of canola grown in sulfur-deficient soils of southwestern Australia. Journal of Plant Nutrition 33:1180-1194.

CAWMA. 2007. Water for food, water for life: A comprehensive assessment of water management in agriculture. London: Earthscan.

Condon, A. G., R. A. Richards, G. J. Rebetzke, and G. D. Farquhar. 2004. Breeding for high wateruse efficiency. Journal of Experimental Botany 55:2447-2460.

Dahnke, W. C., and R. A. Olson. 1990. Soil test calibration and the recommendation. In Soil testing and plant analysis, 3rd ed, ed. R. L. Westerman, 45-71. Madison, Wisc.: Soil Science Society of America. 
El-Swaify, S. A., P. Pathak, T. J. Rego, and S. Singh. 1985. Soil management for optimized productivity under rainfed conditions in the semi-arid tropics. Advances in Soil Science 1:1-64.

Fageria, N. K., V. C. Baligar, and R. B. Clark. 2002. Micronutrients in crop production. Advances in Agronomy 77:185-268.

Graham, R. D., R. M. Welch, D. A. Saunders, I. Ortiz-Monasterio, H. E. Bouis, M. Bonierbale, S. de Haan, G. Burgos, G. Thiele, R. Liria, C. A. Meisner, S. E. Beebe, M. J. Potts, M. Kadian, P. R. Hobbs, R. K. Gupta, and S. Twomlow. 2007. Nutritious subsistence food systems. Advances in Agronomy 92:1-74.

Helmke, P. A., and D. L. Sparks. 1996. Lithium, sodium, potassium, rubidium, and cesium. In Methods of soil analysis, part 3: Chemical methods, ed. D. L. Sparks, 551-574. Madison, Wisc.: SSSA and ASA.

Hiradate, S., J. F. Ma, and H. Matsumoto. 2007. Strategies of plants to adapt to mineral stresses in problem soils. Advances in Agronomy 96:65-132.

Kanwar, J. S. 1972. Twenty-five years of research in soil, fertilizer, and water management in India. Indian Farming 22 (5): 16-25.

Katyal, J. C. 2003. Soil fertility management-A key to prevent desertification. Journal of the Indian Society of Soil Science 51:378-387.

Kelly, T. G., P. Parthasarathy Rao, R. E. Weltzien, and M. L. Purohit. 1996. Adoption of improved cultivars of pearl millet in arid environment: Straw yield and quality consideration in western Rajasthan. Experimental Agriculture 32:161-171.

Keren, R. 1996. Boron. In Methods of soil analysis, part 3: Chemical methods, ed. D. L. Sparks, 603-626. Madison, Wisc.: SSSA and ASA.

Lal, R. 2008. Soils and sustainable agriculture: A review. Agronomy for Sustainable Development 28:57-64.

Lindsay, W. L., and W. A. Norvell. 1978. Development of a DTPA test for zinc, iron, manganese, and copper. Soil Science Society of America Journal 42:421-428.

Mills, H. A., and J. B. Jones Jr. 1996. Plant analysis handbook: A practical sampling, preparation, and interpretation guide. Athens, Ga.: Micro Macro Publishing.

Nelson, D. W., and L. E. Sommers. 1996. Total carbon, organic carbon, and organic matter. In Methods of soil analysis, part 3: Chemical methods, ed. D. L. Sparks, 961-1010. Madison, Wisc.: SSSA and ASA.

Ncube, B., J. P. Dimes, S. J. Twomlow, W. Mupangwa, and K. E. Giller. 2007. Participatory on-farm trials to test response of maize to small doses of manure and nitrogen in small-holder farming systems in semi-arid Zimbabwe. Nutrient Cycling in Agroecosystems 77:53-67.

Olsen, S. R., and L. E. Sommers. 1982. Phosphorus. In Methods of soil analysis, part 2, 2nd ed., ed. A. L. Page, 403-430. Madison, Wisc.: ASA and SSSA.

Parthasarathy Rao, P., P. S. Birthal, B. V. S. Reddy, K. N. Rai, and S. Ramesh. 2006. Diagnostics of sorghum and pearl millet grains-based nutrition in India. International Sorghum and Millets Newsletter 47:93-96.

Pasricha, N. S., and R. L. Fox. 1993. Plant nutrient sulfur in the tropics and subtropics. Advances in Agronomy 50:209-269.

Passioura, J. B. 2006. Increasing crop productivity when water is scarce-From breeding to field management. Agricultural Water Management 80:176-196.

Passioura, J. B., and J. F. Angus. 2010. Improving productivity of crops in water-limited environments. Advances in Agronomy 106:37-74.

Pathak, P., K. L. Sahrawat, S. P. Wani, R. C. Sachan, and R. Sudi. 2009. Opportunities for water harvesting and supplemental irrigation for improving rainfed agriculture in semi-arid areas. In Rainfed agriculture: Unlocking the potential, ed. S. P. Wani, J. Rockström, and T. Oweis, 197-221. Wallingford, UK: CABI.

Rajashekhara Rao, B. K., K. L. Sahrawat, S. P. Wani, and G. Pardhasaradhi. 2010. Integrated nutrient management to enhance on-farm productivity of rain fed maize in India. International Journal of Soil Science 5:216-225. 
Rattan, R. K., K. P. Patel, K. M. Manjaiah, and S. P. Datta. 2009. Micronutrients in soil, plant, animal, and human health. Journal of the Indian Society of Soil Science 57:546-558.

Rego, T. J., V. N. Rao, B. Seeling, G. Pardhasaradhi, and J. V. D. K. Kumar Rao. 2003. Nutrient balances-A guide to improving sorghum and groundnut-based dryland cropping systems in semi-arid tropical India. Field Crops Research 81:53-68.

Rego, T. J., S. P. Wani, K. L. Sahrawat, and G. Pardhasaradhi. 2005. Macro-benefits from boron, zinc, and sulfur application in Indian SAT: A step for gray to green revolution in agriculture (Global Theme on Agroecosystems Report No. 16). Patancheru, India: International Crops Research Institute for the Semi-arid Tropics.

Rego, T. J., K. L., Sahrawat, S. P. Wani, and G. Pardhasaradhi. 2007. Widespread deficiencies of sulfur, boron, and zinc in Indian semi-arid tropical soils: On-farm crop responses. Journal of Plant Nutrition 30:1569-1583.

Reuter, D. J., and J. B. Robinson, eds. 1997. Plant analysis: An interpretation manual, 2nd ed. Melbourne, Australia: CSIRO.

Rockström, J., L. Karlberg, S. P. Wani, J. Barron, N. Hatibu, T. Oweis, A. Bruggeman, J. Farahani, and Z. Qiang. 2010. Managing water in rainfed agriculture-The need for a paradigm shift. Agricultural Water Management 97:543-550.

Saha, J. K., A. B. Singh, A. N. Ganeshamurthy, S. Kundu, and A. K. Biswas. 2001. Sulfur accumulation in Vertisols due to continuous gypsum application for six years and its effect on yield and biochemical constituents of soybean (Glycine Max L. Merrill). Journal of Plant Nutrition and Soil Science 164:317-320.

Sahrawat, K. L. 2006. Plant nutrients: Sufficiency and requirements. In Encyclopedia of soil science, 2nd ed., ed. R. Lal, 1306-1310. Philadelphia, Penn.: Taylor and Francis.

Sahrawat, K. L. 2009. The role of tolerant genotypes and plant nutrients in reducing acid-soil infertility in upland rice ecosystem: An appraisal. Archives of Agronomy and Soil Science 55:597-607.

Sahrawat, K. L., M. K. Abekoe, and S. Diatta. 2001. Application of inorganic phosphorus fertilizer. In Sustaining fertility in West Africa, ed. G. Tian, F. Ishida, and D. Keatinge, 225-246. Madison, Wisc.: SSSA and ASA.

Sahrawat, K. L., S. P. Wani, T. J. Rego, G. Pardhasaradhi, and K. V. S. Murthy. 2007. Widespread deficiencies of sulphur, boron, and zinc in dryland soils of the Indian semi-arid tropics. Current Science 93:1428-1432.

Sahrawat, K. L., T. J. Rego, S. P. Wani, and G. Pardhasaradhi. 2008a. Sulfur, boron, and zinc fertilization effects on grain and straw quality of maize and sorghum grown on farmers' fields in the semi-arid tropical region of India. Journal of Plant Nutrition 31:1578-1584.

Sahrawat, K. L., T. J. Rego, S. P. Wani, and G. Pardhasaradhi. 2008b. Stretching soil sampling to watershed: Evaluation of soil-test parameters in a semi-arid tropical watershed. Communications in Soil Science and Plant Analysis 39:2950-2960.

Sahrawat, K. L., K. V. S. Murthy, and S. P. Wani. 2009. Comparative evaluation of Ca chloride and Ca phosphate for extractable sulfur in soils with a wide range in $\mathrm{pH}$. Journal of Plant Nutrition and Soil Science 172:404-407.

Sahrawat, K. L., S. P. Wani, P. Pathak, and T. J. Rego. 2010a. Managing natural resources of watersheds in the semi-arid tropics for improved soil and water quality: A review. Agricultural Water Management 97:375-381.

Sahrawat, K. L., S. P. Wani, G. Pardhasaradhi, and K. V. S. Murthy. 2010b. Diagnosis of secondary and micronutrient deficiencies and their management in rainfed agroecosystems: Case study from Indian semi-arid tropics. Communications in Soil Science and Plant Analysis 41:346-360.

Sanchez, P. A., K. D. Shepherd, M. J. Soul, F. M. Place, R. J. Buresh, A. M. N. Izac, A. U. Mokwunye, F. R. Kwesiga, C. G. Nderitu, and P. L. Woomer. 1997. Soil fertility replenishment in Africa: An investment in natural resource capital. In Replenishing soil fertility in Africa, eds. R. J. Buresh, P. A. Sanchez, and F. Calhoun, 1-46. Madison, Wisc.: Soil Science Society of America.

Scherer, H. W. 2001. Sulphur in crop production. European Journal of Agronomy 14:81-111.

Scherer, H. W. 2009. Sulfur in soils. Journal of Plant Nutrition and Soil Science 172:326-335. 
Sharma, B. R., K. V. Rao, K. P. R. Vittal, Y. S. Ramakrishna, and U. Amarasinghe. 2010. Estimating the potential of rainfed agriculture in India: Prospects for water productivity improvement. Agricultural Water Management 97:23-30.

Singh, A. K. 2008. Soil resource management-Key to food and health security. Journal of the Indian Society of Soil Science 56:348-357.

Singh, P., P. Pathak, S. P. Wani, and K. L. Sahrawat. 2009. Integrated watershed management for increasing productivity and water-use efficiency in semi-arid tropical India. Journal of Crop Improvement 23:402-429.

Srinivasarao, Ch., S. P. Wani, K. L. Sahrawat, K. Krishnappa, and B. K. Rajasekhara Rao. 2010. Effect of balanced nutrition on yield and economics of vegetable crops in participatory watersheds in Karnataka. Indian Journal of Fertilisers 6:39-42.

Tabatabai, M. A. 1996. Sulfur. In Methods of soil analysis, part 3: Chemical methods, ed. D. L. Sparks, 921-960. Madison, Wisc.: SSSA and ASA.

Takkar, P. N. 1996. Micronutrient research and sustainable agricultural productivity. Journal of the Indian Society of Soil Science 44:563-581.

Twomlow, S., D. Love, and S. Walker. 2008. The nexus between integrated natural resources management and integrated water resources management in southern Africa. Physics and Chemistry of the Earth 33:889-898.

Twomlow, S., B. Shiferaw, P. Cooper, and J. D. H. Keatinge. 2008. Integrating genetics and natural resource management for technology targeting and greater impact of agricultural research in the semi-arid tropics. Experimental Agriculture 44:235-256.

Usha Rani, K., K. L. Sharma, K. Nagasri, K. Srinivas, T. Vishnu Murthy, G. R. Maruthi Shankar, G. R. Korwar, K. S. Sankar, M. Madhavi, and J. K. Grace. 2009. Response of sunflower to sources and levels of sulfur under rainfed semi-arid tropical conditions. Communications in Soil Science and Plant Analysis 40:2926-2944.

Wani, S. P. 2008. Taking soil science to farmers' doorsteps through community watershed management. Journal of the Indian Society of Soil Science 56:367-377.

Wani, S. P., P. Pathak, H. M. Tam, A. Ramakrishna, P. Singh, and T. K. Sreedevi. 2002. Integrated watershed management for minimizing land degradation and sustaining productivity in Asia. In Integrated land management in dry areas: Proceedings of a Joint UNU-CAS International Workshop, ed. Zafar Adeel, 207-230. Tokyo: United Nations University,

Wani, S. P., P. Pathak, L. S. Jangawad, H. Eswaran, and P. Singh. 2003. Improved management of Vertisols in the semiarid tropics for increased productivity and soil carbon sequestration. Soil Use and Management 19:217-222.

Wani, S. P., T. K. Sreedevi, J. Rockström, and Y. S. Ramakrishna. 2009. Rainfed agriculture-Past trends and future prospects. In Rainfed agriculture: Unlocking the potential, ed. S. P. Wani, J. Rockström, and T. Oweis, 1-35. Wallingford, UK: CAB International.

Zougmore, R., Z. Zida, and N. F. Kambou. 2003. Role of nutrient amendments in the success of halfmoon soil and water conservation practice in semi-arid Burkina Faso. Soil and Tillage Research $71: 143-149$. 